\title{
Comparison of re-micellised casein prepared from acid casein with micellar casein prepared by membrane filtration
}

\author{
John S. MOUNSEY, Brendan T. O'KENNEDY, Philip M. KELLY* \\ Teagasc, Dairy Products Research Centre, Moorepark, Fermoy, Co. Cork, Ireland
}

Published online 24 June 2005

\begin{abstract}
Re-micellised casein was prepared by adding various calcium and phosphate salts to acid casein followed by heating and dispersing in distilled water or simulated milk ultrafiltrate (SMUF). The rheological properties, solubility, particle size, ethanol stability and heat stability of the re-micellised acid casein were examined in water or SMUF and compared with micellar casein prepared by membrane filtration. Acid and rennet gelation behaviour of both micellar casein types was different in water than in SMUF. Re-micellised casein had poorer acid gelation properties than phosphocasein but formed stronger rennet gels. Re-micellised casein exhibited increased heat stability at $\mathrm{pH} \leq 6.6$ under both low and higher ionic strength conditions compared with phosphocasein. Ethanol stability was greater in SMUF than in water. Differences between re-micellised casein and phosphocasein were attributed to the inherent increased ionic strength of re-micellised casein dispersions. It was shown that insoluble acid casein could be successfully re-micellised while retaining good functionality.
\end{abstract}

re-micellisation / acid casein / phosphocasein / ionic strength

Résumé - Comparaison de micelles de caséine reconstituées préparées à partir de caséine acide avec des micelles de caséine obtenues par filtration sur membrane. Des micelles de caséine reconstituées étaient préparées par addition de différents sels de calcium et de phosphate à de la caséine acide, suivie d'un traitement thermique et d'une dispersion dans de l'eau distillée ou dans un ultrafiltrat de lait simulé (SMUF). Les propriétés rhéologiques, la solubilité, la taille de particules ainsi que la stabilité thermique et à l'éthanol, étaient étudiées dans de l'eau ou dans le SMUF et comparées avec celles de micelles de caséine obtenues par filtration sur membrane. Les propriétés de coagulation par acidification et par action de la présure différaient dans l'eau ou dans le SMUF. Les micelles de caséine reconstituées avaient de plus faibles propriétés de gélification acide que la phosphocaséine mais formaient des gels présure plus forts. Elles montraient une stabilité thermique accrue à $\mathrm{pH} \leq 6,6$ pour des conditions de force ionique basse et plus élevée, comparée à celle de la phosphocaséine. La stabilité à l'éthanol était plus élevée dans le SMUF que dans l'eau. Les différences entre les micelles de caséine reconstituées et la phosphocaséine ont été attribuées à l'augmentation inhérente de la force ionique dans les dispersions de micelles de caséine reconstituées. Ces résultats montrent que des caséines acides insolubles pourraient être remises sous forme de micelles tout en retenant une bonne fonctionnalité.

re-micellisation / caséine acide / phosphocaséine / force ionique

\footnotetext{
* Corresponding author: pkelly@ moorepark.teagasc.ie
} 


\section{INTRODUCTION}

The commercial manufacture of acid casein from skim milk has been reviewed by Mulvihill [16]. It involves acidification, using rapid injection of sufficient mineral acid $(\mathrm{HCl})$ into pasteurised $\left(72{ }^{\circ} \mathrm{C}\right.$ for $\left.15 \mathrm{~s}\right)$ skim milk at $30^{\circ} \mathrm{C}$, to alter the $\mathrm{pH}$ to 4.4 4.7 (the isoelectric point of the casein). Alternatively, lactic casein can be produced through fermentation of the skim milk, giving a slower coagulation but a more natural process. The pasteurisation temperature used causes minimal denaturation of whey proteins, preventing their interaction with the casein. Casein as it exists in fresh skim milk is in micellar form (particles with diameters in the range $60-300 \mathrm{~nm}$ ) and as such contains large concentrations of colloidal calcium phosphate. At the isoelectric $\mathrm{pH}$, however, colloidal calcium and phosphate become soluble and remain with the whey following separation from the casein. Commercially, the casein curd is then washed to eliminate residual lactose, soluble salts and native whey proteins, before being dried.

Horne [8] associates casein aggregation on acidification with a change in the balance between electrostatic and hydrophobic forces. At minimum electrostatic repulsion (isoelectric point) hydrophobic forces are allowed to dominate and aggregation and gelation follow. De Kruif [4] suggested that the casein micelle had a stabilising brush layer of $\kappa$-casein on the particle surface. On lowering the $\mathrm{pH}$, the charged groups on the stabilising layer are neutralised, leading to the eventual collapse and the formation of a particulate three-dimensional gel network. While acid casein is dried at its isoelectric $\mathrm{pH}$, functionality is not restored until dispersability is achieved through a subsequent increase in $\mathrm{pH}$ by alkali addition. The alkali used is usually sodium hydroxide, yielding the associated sodium caseinate. However, calcium, potassium and ammonium hydroxide have been used. These caseinates are high protein ingredients, up to $90 \%$ protein in dry matter, and have large applications in the food industry as emulsifiers.

Phosphocasein, a general term to describe isolated micellar casein, is generally pro- duced by microfiltration without a precipitation step [26]. This results in the elimination of the whey protein, lactose and soluble salt fractions, while retaining the micellar casein with its associated colloidal calcium phosphate. Due to the inherent low ionic strength conditions prevailing in phosphocasein dispersions, stability to flocculation at processing temperatures $\left(60-80^{\circ} \mathrm{C}\right)$ is limited [15]. Phosphocasein exhibits physico-chemical and micellar behaviour similar to milk in terms of particle size, rennet gelation [20] and acid gelation [5]. Little is available in the literature on the corresponding properties of casein re-micellised from acid casein. Re-micellisation of acid casein involves $\mathrm{pH}$ adjustment to 7.0 with the concomitant reintroduction of the colloidal calcium phosphate.

The objective of this work was to compare the functional attributes of casein on re-micellisation from acid casein with phosphocasein prepared by microfiltration.

\section{MATERIALS AND METHODS}

\subsection{Materials}

Phosphocasein (803 $\mathrm{g} \cdot \mathrm{kg}^{-1}$ protein, $19 \mathrm{~g} \cdot \mathrm{kg}^{-1}$ lactose, $43 \mathrm{~g} \cdot \mathrm{kg}^{-1}$ fat, $79 \mathrm{~g} \cdot \mathrm{kg}^{-1}$ ash and $56 \mathrm{~g} \cdot \mathrm{kg}^{-1}$ moisture) was prepared in-house as described by Kelly et al. [14]. Acid casein $\left(880 \mathrm{~g} \cdot \mathrm{kg}^{-1}\right.$ protein, $95 \mathrm{~g} \cdot \mathrm{kg}^{-1}$ moisture, $8 \mathrm{~g} \cdot \mathrm{kg}^{-1}$ fat, $15 \mathrm{~g} \cdot \mathrm{kg}^{-1}$ ash) was obtained from Dairygold (Mitchelstown, Co. Cork, Ireland). Deionised water was used in all cases for dispersion of samples. 1,5-Gluconolactone (GDL) was obtained from Fischer Scientific (Leicestershire, UK). CHY-MAX Ultra was obtained from Chr. Hansen Ireland (Chr. Hansen's Laboratory, Little Island, Cork, Ireland). All other chemicals were Analar grade and supplied by BDH (Poole, England). Absolute ethanol was obtained from Merck KgaA, Darmstadt, Germany.

\subsection{Re-micellisation of acid casein}

Acid casein was dispersed in distilled deionised water to give a final protein concentration of $88 \mathrm{~g} \cdot \mathrm{kg}^{-1}$ following conversion to 
the micellar form. The casein slurry was mixed at $22{ }^{\circ} \mathrm{C}$ for 5 min using a Silverson mixer (Silverson Machines Ltd., Waterside, Chesham, Bucks, England) at $5000 \mathrm{rpm}$ to aid in protein hydration. A $100 \mathrm{~g} \cdot \mathrm{kg}^{-1}$ $\mathrm{Ca}(\mathrm{OH})_{2}$ slurry was added to the acid casein to give a pH of 7.1 after 15 min. Typically this contributed $18 \mathrm{mg} \mathrm{Ca}^{-1}$ protein in the converted dispersion. Equal quantities of $\mathrm{CaCl}_{2} \cdot 2 \mathrm{H}_{2} \mathrm{O}\left(113 \mathrm{~g} \cdot \mathrm{kg}^{-1}\right.$, aqueous solution) and $\mathrm{Na}_{2} \mathrm{HPO}_{4}\left(116 \mathrm{~g} \cdot \mathrm{kg}^{-1}\right.$, aqueous solution) were simultaneously added to the calcium caseinate dispersion. Mixing was continuous until conversion was complete. Typically the final dispersion contained $36 \mathrm{mg} \mathrm{Ca}$ and $18 \mathrm{mg} \mathrm{P} \cdot \mathrm{g}^{-1}$ protein, and had a $\mathrm{Ca} / \mathrm{P}$ molar ratio of 1.55 . Sufficient $\mathrm{NaOH}$ was added to give a final $\mathrm{pH}$ of 7.0. The converted calcium phosphate caseinate was heated to $60{ }^{\circ} \mathrm{C}$ for $20 \mathrm{~min}$. For determination of the functional attributes of interest, the $88 \mathrm{~g} \cdot \mathrm{kg}^{-1}$ protein dispersion was diluted to 25 or $50 \mathrm{~g} \cdot \mathrm{kg}^{-1}$ protein at $5^{\circ} \mathrm{C}$ in distilled de-ionised water, or in lactose-free simulated milk ultrafiltrate (SMUF, Jenness and Koops [13]) containing the specified salts (SMUF) or double the specified salts (SMUF×2) normally present in milk, as outlined by Auty et al. [1]. The dispersion of micellar casein in SMUF or SMUF $\times 2$ was undertaken at $5{ }^{\circ} \mathrm{C}$ to maximise the solubility of the complex salt solution. Finally, the diluted micellar casein dispersions were heated to $80^{\circ} \mathrm{C}$ for $20 \mathrm{~min}$ and cooled immediately in a water bath at $22{ }^{\circ} \mathrm{C}$ and stored overnight at $4{ }^{\circ} \mathrm{C}$.

\subsection{Preparation of phosphocasein dispersions}

The phosphocasein was dispersed in distilled de-ionised water at $100 \mathrm{~g} \cdot \mathrm{kg}^{-1}$ protein at $40{ }^{\circ} \mathrm{C}$ for $10 \mathrm{~min}$ using a Silverson mixer at $5000 \mathrm{rpm}$ to aid in protein hydration. This was cooled and then diluted to $25 \mathrm{~g} \cdot \mathrm{kg}^{-1}$ or $50 \mathrm{~g} \cdot \mathrm{kg}^{-1}$ protein levels in water, SMUF or $\mathrm{SMUF} \times 2$ at $22^{\circ} \mathrm{C}$. The $\mathrm{pH}$ was adjusted using $1 \mathrm{~mol} \cdot \mathrm{L}^{-1} \mathrm{HCl}$ or $\mathrm{NaOH}$.

\subsection{Acid gel formation}

Gel formation during acidification of the protein solutions was determined using a controlled stress Bohlin CVO Rheometer (Bohlin, Cirencester, UK) at $40^{\circ} \mathrm{C}$. Predetermined quantities of GDL (sufficient to achieve a $\mathrm{pH}$ of 4.6 in $120 \mathrm{~min}$ ) were added to the protein solutions at $5{ }^{\circ} \mathrm{C}$ with vigorous stirring for $1 \mathrm{~min}$ before $13 \mathrm{~mL}$ was transferred to the rheometer. GDL was added at levels of 23,25 or $27 \mathrm{~g} \cdot \mathrm{kg}^{-1}$ to $50 \mathrm{~g} \cdot \mathrm{kg}^{-1}$ protein dispersions of re-micellised casein in water, SMUF or SMUF $\times 2$, respectively. Dispersions of $50 \mathrm{~g} \cdot \mathrm{kg}^{-1}$ phosphocasein protein in water, SMUF or SMUF $\times 2$ required 20,23 or $26 \mathrm{~g} \cdot \mathrm{kg}^{-1}$ of GDL, respectively, to reach a $\mathrm{pH}$ of 4.6 in $120 \mathrm{~min}$. The $\mathrm{pH}$ of the samples was measured using an Orion Ross pH8115SC combination electrode attached to an Orion model 420A pH meter (Orion research, Inc., Beverly, MA, USA). The rheometer was used in the dynamic mode for smallscale deformation measurements. A concentric cylinder (C25) measurement system was used. The diameter of the bob was $25 \mathrm{~mm}$ and the internal diameter of the cup was $27.5 \mathrm{~mm}$. All measurements were taken at $40{ }^{\circ} \mathrm{C}$. Measurements were taken at a frequency of $1 \mathrm{~Hz}$ and at a maximum strain of 0.0103. n-Tetradecane (Sigma Chemical Co., St. Louis, MO, USA) was added to the surface of the rheometer cup to avoid evaporation. G' (elastic modulus), G' (viscous modulus) and Tan $\delta$ (ratio between $G^{\prime}$ ' and G') were measured at $1 \mathrm{~min}$ intervals at $40^{\circ} \mathrm{C}$ over a $120 \mathrm{~min}$ period. All experiments were duplicated. A duplicate sample was routinely monitored for the effect of GDL on the $\mathrm{pH}$ of the sample over time. The gelation time and $\mathrm{pH}$ were taken as the point at which $\mathrm{G}^{\prime} \geq 1.0 \mathrm{~Pa}$. The final gel strength was defined as $G^{\prime}$ after $120 \mathrm{~min}$.

\subsection{Rennet gel formation}

For rennet gelation, the same small-scale oscillation test and measurement system as described in section 2.4 was employed, using a temperature of $31^{\circ} \mathrm{C}$ and test duration of $1 \mathrm{~h}$. Calcium chloride $\left(2 \mathrm{mmol} \cdot \mathrm{L}^{-1}\right)$ was added to casein dispersions $\left(25 \mathrm{~g} \cdot \mathrm{kg}^{-1}\right.$ protein), the $\mathrm{pH}$ adjusted to 6.60 and the sample incubated at $31^{\circ} \mathrm{C}$ for $30 \mathrm{~min}$. Chy$\operatorname{mosin}\left(0.18 \mathrm{~mL} \cdot \mathrm{kg}^{-1}\right)$ was added with mixing 
for $20 \mathrm{~s}$ and $13 \mathrm{~mL}$ of the mixture was transferred to the rheometer. All experiments were duplicated. The gelation time was taken as the point at which $\mathrm{G}^{\prime} \geq 1.0 \mathrm{~Pa}$ and the final gel strength was defined as $G$ ' after $60 \mathrm{~min}$.

\subsection{Sedimentation test}

A $50 \mathrm{~mL}$ aliquot of the $25 \mathrm{~g} \cdot \mathrm{kg}^{-1}$ of remicellised casein or phosphocasein dispersions was centrifuged in a Super Vario N centrifuge (Funke Gerber, Germany) for $5 \mathrm{~min}$ at $900 \mathrm{~g}$ in a $50-\mathrm{mL}$ graduated glass tube (Elkay, MA, USA) at $22{ }^{\circ} \mathrm{C}$. The volume of sediment was expressed as $\mathrm{mL} \cdot 50 \mathrm{~mL}^{-1}$.

\subsection{Particle size}

Particle size analysis was performed at $22{ }^{\circ} \mathrm{C}$ on the supernatant from the sedimentation test (Sect. 2.6) using a Malvern Zetamaster (model 7EM; Malvern Instruments Ltd, Worcester, UK). The cumulative method was used to find the mean average (z-average) or the size of a particle that corresponds to the mean of the intensity distribution. Samples were diluted in SMUF or water at a $\mathrm{pH}$ of 6.60 to come within the desired limits of the Zetamaster (60-90 kilocounts $\cdot \mathrm{s}^{-1}$ )

\subsection{Ethanol stability test}

Solutions of casein $\left(25 \mathrm{~g} \cdot \mathrm{L}^{-1}\right.$ protein $)$ in SMUF or water were prepared at various $\mathrm{pH}$ values (6.4-7.0) by adjustment with $0.5 \mathrm{~mol} \cdot \mathrm{L}^{-1} \mathrm{HCl}$ or $\mathrm{NaOH}$. The ethanol stability was determined using the method of O'Kennedy et al. [17]. This involved the addition of ethanol $\left(990 \mathrm{~mL} \cdot \mathrm{L}^{-1}\right.$ alcohol $)$ to a $20-\mathrm{mL}$ solution of casein solution (25 $\mathrm{g} \cdot \mathrm{kg}^{-1}$ protein) in SMUF at $22{ }^{\circ} \mathrm{C}$ until the casein visibly precipitated.

\subsection{Heat stability test}

Solutions of casein $\left(25 \mathrm{~g} \cdot \mathrm{L}^{-1}\right.$ protein $)$ in SMUF or water were prepared at various $\mathrm{pH}$ values $(6.4-7.0)$ by adjustment with $0.5 \mathrm{~mol} \cdot \mathrm{L}^{-1} \mathrm{HCl}$ or $\mathrm{NaOH}$ at $22^{\circ} \mathrm{C}$. Heat stability was assessed by a modification of the test of Davies and White [3]. Samples $(3.5 \mathrm{~mL})$ were enclosed into a narrow glass tube, which was inserted into a swinging rack placed in a temperature controlled oilbath (Elbanton, 5331 EJ Kerkdriel, Holland) at $140{ }^{\circ} \mathrm{C}$. The samples in the oil-bath were rocked $\left(8\right.$ oscillations $\cdot$ min $\left.^{-1}\right)$. HCT (heat coagulation time) was defined as the time for visual coagulation to occur.

\section{RESULTS AND DISCUSSION}

\subsection{Re-micellisation}

Production of micellar casein from acid casein is not a simple reversal of the processes required to make acid casein from skim milk. The components of interest in this reversal are casein in its isoelectric form (insoluble), calcium and phosphate. Intrinsically superimposed on the behaviour of these components is the necessity to increase the $\mathrm{pH}$ from 4.6 to $\sim 7.0$. The $\mathrm{pH}$ titration confers an overall negative charge on the casein allowing it to disaggregate, while calcium phosphate formation is encouraged at the higher $\mathrm{pH}$, especially at higher temperatures. In this study, $\mathrm{Ca}(\mathrm{OH})_{2}$ was used to increase the $\mathrm{pH}$ and essentially micellise the acid casein in the form of calcium caseinate. The re-micellised calcium

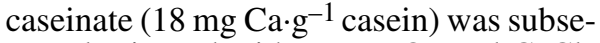
quently titrated with $\mathrm{Na}_{2} \mathrm{HPO}_{4}$ and $\mathrm{CaCl}_{2}$ with $\mathrm{pH}$ control, allowing the casein to protect the nanoclusters of calcium phosphate formed in the process. The requirements of the process were to produce casein particles which were sufficiently small to be stable to sedimentation and exhibit functionality which was similar to the more natural phosphocasein produced by microfiltration. It was never likely, or expected, that the remicellisation process would produce casein particles identical to the native micelle.

Temperature control was important during the re-micellisation process - a temperature of $22{ }^{\circ} \mathrm{C}$ being maintained while the calcium and phosphate salts were added. Roeper [22] found for the conversion of acid casein to calcium caseinate that a temperature not exceeding $40{ }^{\circ} \mathrm{C}$ was necessary to aid protein hydration and reduce 


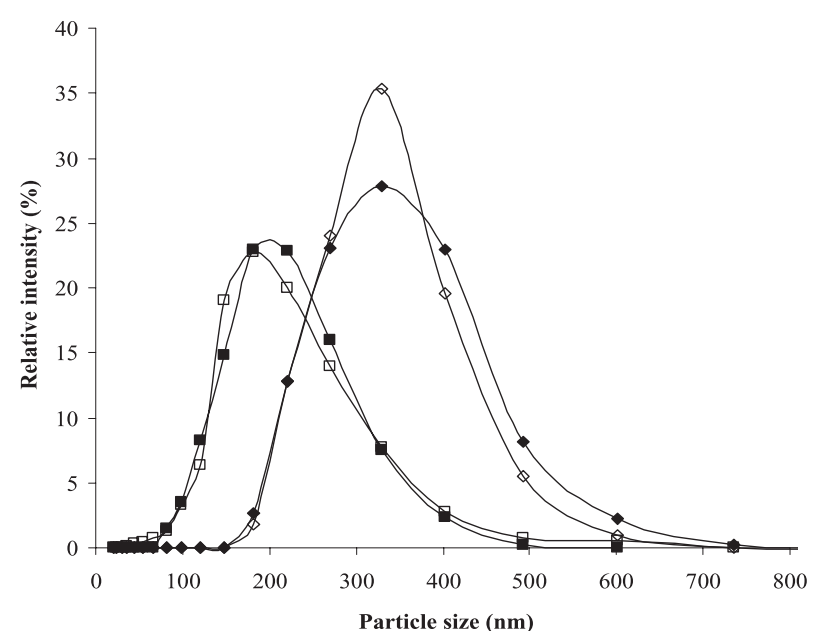

Figure 1. Particle size distribution ( $\mathrm{pH}$ 6.60) of re-micellised casein diluted in SMUF $(\downarrow)$ or water $(\diamond)$ or phosphocasein diluted in SMUF (ם) or water ( $\square$ ). sediment formation. The re-micellised casein was subsequently heated at $60{ }^{\circ} \mathrm{C}$ for $20 \mathrm{~min}$ to aid the conversion process and minimise the production of sedimentable material [22]. Samples were subsequently cooled to $5^{\circ} \mathrm{C}$. Following dilution of the re-micellised casein in water or SMUF $\left(5^{\circ} \mathrm{C}\right)$, heating at $80{ }^{\circ} \mathrm{C}$ for $20 \mathrm{~min}$ was used both to pasteurise and complete the conversion process. The re-micellised casein samples were prepared fresh and functional behaviour assessed without subsequent drying and reconstitution. The phosphocasein was a dried powder and hence could be reconstituted in water, SMUF or SMUF $\times 2$ as desired. For comparative purposes and for ease of description we term the initial remicellised casein sample as having water as the solvent and SMUF or SMUF $\times 2$ terminology where the water solvent is adjusted through dilution with SMUF concentrates. These dilutions were always performed at low temperatures $\left(<5{ }^{\circ} \mathrm{C}\right)$ to minimise mineral interactions. While $\beta$-casein and mineral partition from the colloidal to the soluble phase occurs at low temperature [2] subsequent heating $\left(80^{\circ} \mathrm{C}\right.$ for $20 \mathrm{~min}$ ) will reverse the process.

The volume of sedimentable material was higher in the re-micellised samples than the reconstituted phosphocasein. The volume of sediment present in $25 \mathrm{~g} \cdot \mathrm{kg}^{-1}$ re-micellised casein in water was $0.175 \pm$ $0.04 \mathrm{~mL} \cdot 50 \mathrm{~mL}^{-1}$, while the sediment in SMUF was $0.185 \pm 0.05 \mathrm{~mL} \cdot 50 \mathrm{~mL}^{-1}$. The volume of sediment in $25 \mathrm{~g} \cdot \mathrm{kg}^{-1}$ phosphocasein in water or SMUF was $0.1 \pm$ $0.05 \mathrm{~mL} \cdot 50 \mathrm{~mL}^{-1}$ or $0.1 \pm 0.05 \mathrm{~mL} \cdot 50 \mathrm{~mL}^{-1}$, respectively. It is difficult to produce calcium caseinates with no sediment [22] but the levels observed in this study were acceptable.

The particle size distribution of re-micellised casein or phosphocasein determined at $\mathrm{pH} 6.60$ in SMUF or water is shown in Figure 1. Re-micellised casein in SMUFhad an average particle size of $294.7 \pm 3.5 \mathrm{~nm}$, which was larger than that obtained for re-micellised casein in water $(269.7 \pm 7 \mathrm{~nm})$. Phosphocasein had larger average particle size $(195 \pm 3 \mathrm{~nm})$ in SMUF than in water $(182 \pm 2.3 \mathrm{~nm})$, in agreement with the findings of Famelart et al. [5]. The casein micelles produced during the re-micellisation process were larger than those present in reconstituted phosphocasein. Schmidt et al. [24] produced artificial casein micelles from casein fractions and also found them to be larger in size than the casein micelles of skim milk. It has been shown both for natural [23] and artificial [24, 25] casein micelles that increasing the $\mathrm{K}$-casein content reduced the particle size. However, it is not surprising that casein micelles, 


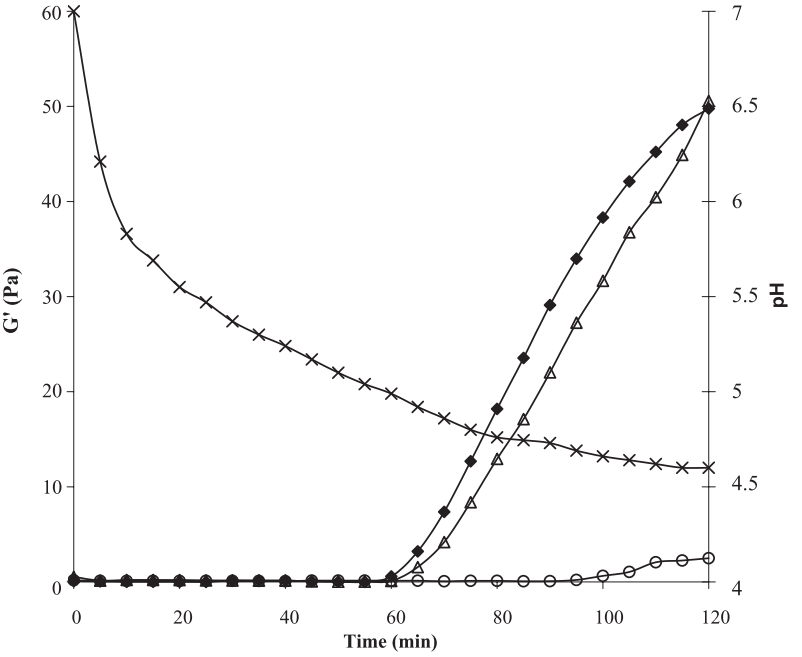

Figure 2. Acid gelation profiles $\left(40{ }^{\circ} \mathrm{C}\right)$ of re-micellised casein $\left(50 \mathrm{~g}\right.$ protein $\left.\cdot \mathrm{kg}^{-1}\right)$ in water $(\checkmark)$, SMUF $(\Delta)$ or SMUF×2 (O). Typical $\mathrm{pH}$ curve $(\mathrm{X})$ is included. formed during the re-micellisation process used in this study, are different (larger). The concomitant increase in $\mathrm{pH}$ and caseinmineral interactions is complex and bears no resemblence to the natural formation of micellar casein. However, the ability to produce re-micellised casein from an acid casein precursor and achieve an average micelle size of $250-300 \mathrm{~nm}$ is technically important.

\subsection{Acid gel formation}

The effect of acidification on the rheological behaviour (expressed as $\mathrm{G}^{\prime}$ ) of $50 \mathrm{~g} \cdot \mathrm{kg}^{-1}$ re-micellised casein in water, SMUF or SMUF $\times 2$ is shown in Figure 2. The remicellised casein in SMUF $\times 2$ commenced gelation $\left(\mathrm{G}^{\prime}\right.$ of $\left.>1 \mathrm{~Pa}\right)$ at $\mathrm{pH} 4.66 \pm 0.06$ with a final gel strength $\left(\mathrm{G}^{\prime}{ }_{120}\right)$ of $2.1 \pm 0.57 \mathrm{~Pa}$. When dispersed in SMUF, gelation commenced at $\mathrm{pH} 4.91 \pm 0.06$ with a final gel strength of $52.4 \pm 2.3 \mathrm{~Pa}$. When dispersed in water, gelation commenced at $\mathrm{pH} 4.93 \pm$ 0.03 with a final gel strength of $49.9 \pm 4.2 \mathrm{~Pa}$. In contrast to re-micellised casein, $50 \mathrm{~g} \cdot \mathrm{kg}^{-1}$ phosphocasein in SMUF $\times 2$ commenced gelation at $\mathrm{pH} 4.90 \pm 0.03$ (Fig. 3) with a final gel strength $\left(\mathrm{G}^{\prime}{ }_{120}\right)$ of $28.8 \pm 3.2 \mathrm{~Pa}$. When dispersed in SMUF gelation commenced at $\mathrm{pH} 5 \pm 0.05$ with a final gel strength $\left(\mathrm{G}^{\prime}{ }_{120}\right)$ of $355 \pm 17.7 \mathrm{~Pa}$. When dispersed in water gelation commenced at $\mathrm{pH} 6.2 \pm 0.01$ and reached a peak in gel strength after $15 \mathrm{~min}(237 \mathrm{~Pa})$ before decreasing to an apparent final gel strength of $13.9 \pm 10.8 \mathrm{~Pa}$.

Roefs and van Vliet [21] have shown that increased ionic strength of acidified skim milk resulted in decreased gel strength. WalshO'Grady et al. [31] suggested that acid gel formation can be inhibited when the ionic strength is high enough. Both the gel point and final gel strength at $\mathrm{pH} 4.6$ have been shown to be dependent on the ionic strength [1]. Famelart et al. [5] observed that acid gels from phosphocasein dispersed in water had larger more hydrated particles compared to the smaller particles, which formed in clusters in acid gelled phosphocasein in SMUF.

While the acid gelation behaviour of both re-micellised and phosphocasein show the same trend in ionic strength dependence, namely, higher gel points at lower ionic strengths and the propensity to be weaker at $\mathrm{pH} 4.6$, it should be noted that this applies to the conditions used in this study and different results may occur at longer times and/or lower $\mathrm{pH}$ values. However, there were marked differences between the acid gelation behaviour of re-micellised casein and phosphocasein dispersions. The high 


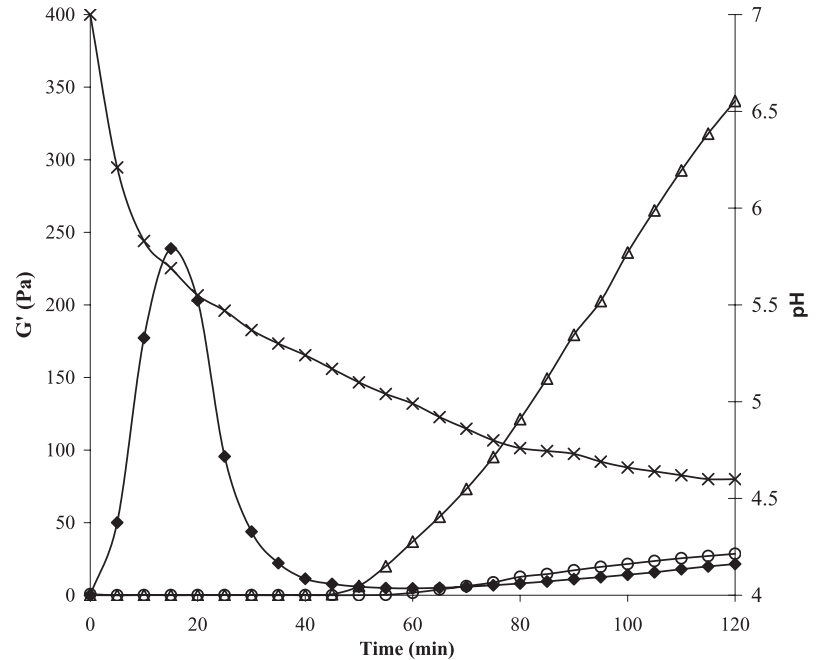

Figure 3. Acid gelation profiles $\left(40{ }^{\circ} \mathrm{C}\right)$ of phosphocasein $\left(50 \mathrm{~g}\right.$ protein $\left.\cdot \mathrm{kg}^{-1}\right)$ in water $(\diamond), \operatorname{SMUF}(\Delta)$ or SMUF $\times 2$ (O). Typical $\mathrm{pH}$ curve $(x)$ is included.
$\mathrm{pH}$ of gelation and the presence of a $\mathrm{G}^{\prime}$ maximum in $50 \mathrm{~g} \cdot \mathrm{kg}^{-1}$ phosphocasein dispersed in water indicated the lack of stability to $\mathrm{pH}$ reduction of the casein micelle and the coarse strength of the matrix in the absence of the stabilising influence of milk salts. Re-micellised casein did not exhibit these characteristics under nominally the same conditions. When re-micellised casein and phosphocasein were dispersed in SMUF $\times 2$, their acid gelation behaviours were markedly different. De Kruif [4] has emphasised the importance of $\kappa$-casein in maintaining the stability of micellar casein to decreasing $\mathrm{pH}$. The stabilising role of increasing ionic strength should therefore be attributed to an increase in the $\kappa$-casein charge density. The differences in acid gelation behaviour between re-micellised casein and phosphocasein could therefore be ascribed to differences in ionic strength. The method of manufacture determines the residual ionic strength present in the aqueous phase. The extent of diafiltration during production of phosphocasein determines the content of whey protein, lactose and soluble salts in the serum phase. These are normally quite low and are responsible for the inherent instability of phosphocasein at high $\mathrm{pH}$ values (gel point at $\mathrm{pH}$ 6.2). The process used in this study for the production of re-micellised casein utilised both $\mathrm{CaCl}_{2}$ and $\mathrm{Na}_{2} \mathrm{HPO}_{4}$ as precursors to calcium phosphate formation, the resulting $\mathrm{NaCl}$ production being estimated at $45 \mathrm{mmol} \cdot \mathrm{L}^{-1}$. This inherent contribution to the ionic strength of the aqueous phase determined the increased stability of the micellar casein without added SMUF to decreased $\mathrm{pH}$.

\subsection{Rennet gel formation}

The rennet coagulation properties of $25 \mathrm{~g} \cdot \mathrm{kg}^{-1}$ protein dispersions produced from re-micellised casein or phosphocasein in SMUF or water are outlined in Figure 4. Re-micellised casein in water had a rennet coagulation time (RCT) of $12 \pm 1.2 \mathrm{~min}$ and a final gel strength of $52.8 \pm 4.5$ Pa after $60 \mathrm{~min}$. When re-micellised casein was dispersed in SMUF it had a RCT of $23 \pm 2.2 \mathrm{~min}$ and a final gel strength of $30.3 \pm 3.4 \mathrm{~Pa}$.

Phosphocasein dispersed in water had a RCT of 7.8 \pm 4.6 min and a final gel strength of $38.40 \pm 3.5 \mathrm{~Pa}$ after $60 \mathrm{~min}$. When phosphocasein was dispersed in SMUF the RCT increased to $13.3 \pm 1.8 \mathrm{~min}$ and the final gel strength decreased to $25.6 \pm 0.64 \mathrm{~Pa}$. Famelart et al. [5] had similar findings for phosphocasein. They found that decreasing the ionic strength of the solvent leads to a reduction in the RCT from $23 \mathrm{~min}$ to $8 \mathrm{~min}$. Similar effects of ionic strength have been obtained for milk [7, 29]. Pierre et al. [19] 


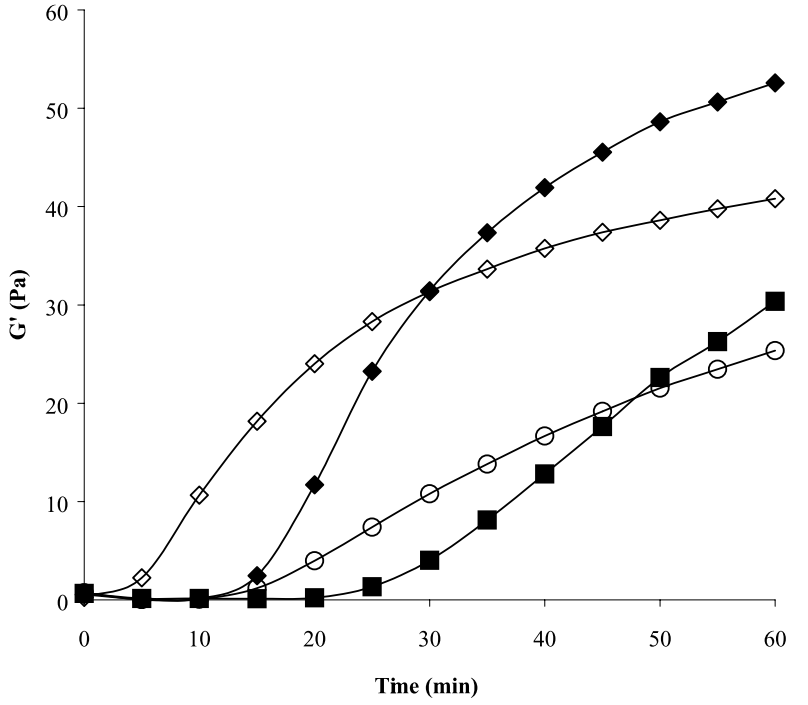

Figure 4. Rennet gelation profiles $\left(25 \mathrm{~g}\right.$ protein $\left.\cdot \mathrm{kg}^{-1}, 31^{\circ} \mathrm{C}\right)$ of re-micellised casein in SMUF $(\boldsymbol{\square})$ or water $(\checkmark)$ or phosphocasein in SMUF (O) or water $(\diamond)$. obtained a lower RCT and greater gel strength using phosphocasein in water compared to milk. It has been suggested that $85 \%$ of $\kappa$-casein hydrolysis occurred prior to coagulation in milk [6]. Increased ionic strength reduced the rate of hydrolysis of $\kappa$-casein in model systems, particularly at higher $\mathrm{pH}$ values. Visser et al. [30] suggested that increased ionic strength lowered the enzyme-substrate attraction by screening the negative charge on chymosin and the positive clusters in $\kappa$-casein.

In general, the RCT and the gel strength at $60 \mathrm{~min}$ of both phosphocasein and remicellised casein were related to the ionic strength of the solvent. It is probable that increased ionic strength increased the charge density of the $\kappa$-casein (see acid stability in Figs. 2 and 3) which in turn conferred an inherent stability to the casein micelle at $\mathrm{pH}$ 6.6. A combination of ionic strength and degree of enzymatic hydrolysis would therefore dictate the RCT. At low ionic strength less hydrolysis would be required for the RCT to become apparent, as the stability of the micellar casein to aggregation reactions is already low. The increased stability of re-micellised casein to coagulation (longer RCT) under both low and higher ionic strength conditions can again be ascribed to the inherent level of
$\mathrm{NaCl}$ present as a result of the micellisation procedure $\left(>23 \mathrm{mmol} \cdot \mathrm{L}^{-1}\right)$.

\subsection{Ethanol stability}

Casein or milk stability to ethanol is dependent on factors such as $\mathrm{pH}$, soluble salts $[9,10]$ the dielectric constant $[11]$ and micellar charge [12]. Pierre [18] observed that ethanol shifted the $\mathrm{pH}$ of minimum stability of both sodium caseinate and milk to higher values. The ethanol stability/pH profile of $25 \mathrm{~g} \cdot \mathrm{kg}^{-1}$ re-micellised casein and phosphocasein are outlined in Figure 5. In general, increasing the $\mathrm{pH}$ from 6.4 to 7.0 resulted in an increase in ethanol stability for all samples. Phosphocasein dispersed in water had very low tolerance to ethanol, coagulating at $91 \pm 25 \mathrm{~mL} \cdot \mathrm{L}^{-1}$ ethanol at $\mathrm{pH} 6.4$ and $230 \pm 4.5 \mathrm{~mL} \cdot \mathrm{L}^{-1}$ ethanol at $\mathrm{pH}$ 7.0. Dispersing the phosphocasein in SMUF increased the ethanol stability to $200 \pm 3.2 \mathrm{~mL} \cdot \mathrm{L}^{-1}$ at $\mathrm{pH} 6.4$ and $650 \pm 5.4 \mathrm{~mL} \cdot \mathrm{L}^{-1}$ at $\mathrm{pH} 7.0$. Re-micellised casein in water coagulated at $167 \pm 4.8 \mathrm{~mL} \cdot \mathrm{L}^{-1}$ ethanol at $\mathrm{pH} 6.4$, increasing to $587 \pm 5.3 \mathrm{~mL} \cdot \mathrm{L}^{-1}$ ethanol at $\mathrm{pH} 7.0$. Dispersing the re-micellised casein in SMUF resulted in coagulation at $310 \pm 4.2 \mathrm{~mL} \cdot \mathrm{L}^{-1}$ ethanol at $\mathrm{pH} 6.4$ which increased to $646 \pm 12.7 \mathrm{~mL} \cdot \mathrm{L}^{-1}$ ethanol at $\mathrm{pH}$ 7.0. The sigmoidal shapes of the ethanol stability 

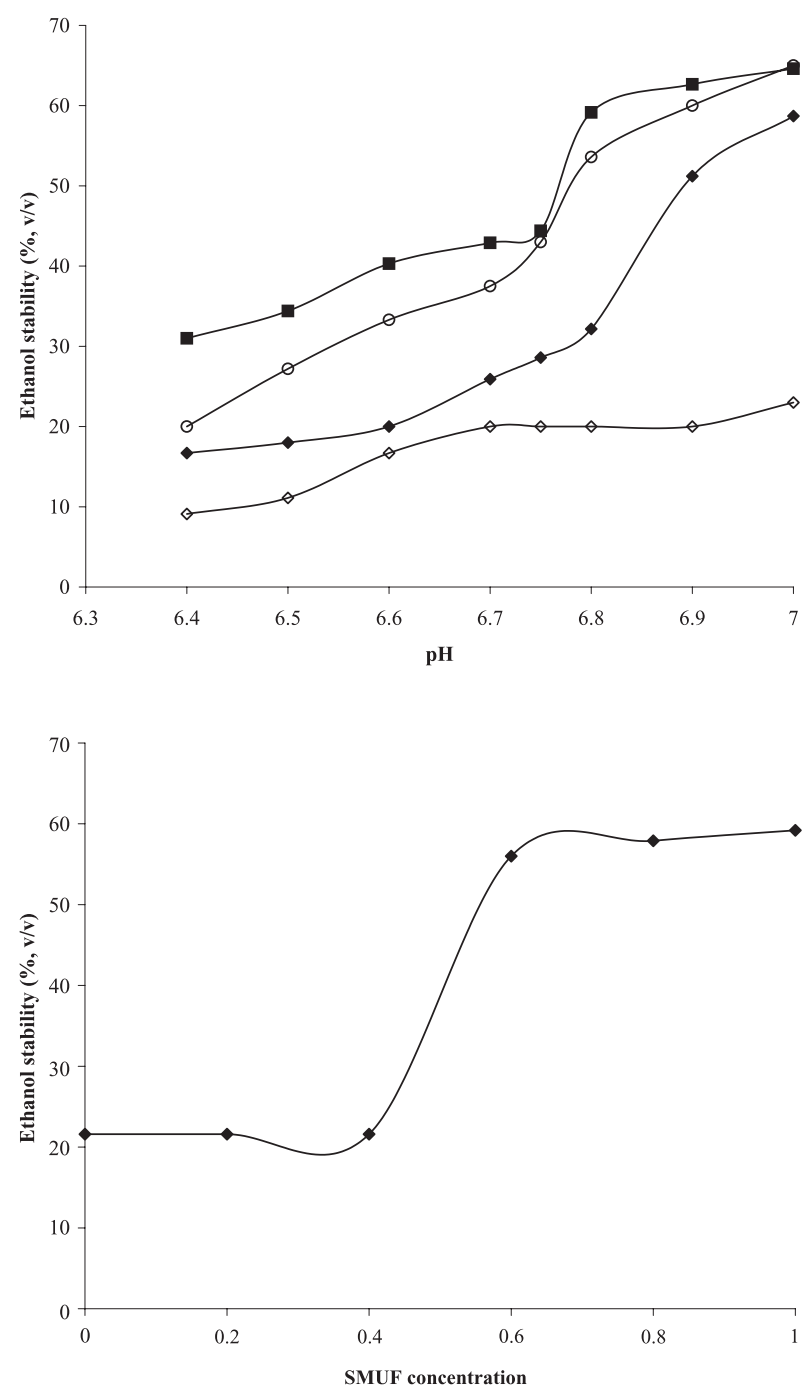

Figure 5. Ethanol stability/pH profiles $\left(25 \mathrm{~g}\right.$ protein $\cdot \mathrm{kg}^{-1}$, $22{ }^{\circ} \mathrm{C}$ ) of re-micellised casein in SMUF $(\mathbf{\square})$ or water $(\boldsymbol{)})$ or phosphocasein in SMUF $(\mathrm{O})$ or water $(\diamond)$.

Figure 6. Ethanol stability $\left(22^{\circ} \mathrm{C}, \mathrm{pH} 7\right)$ of phosphocasein $\left(25 \mathrm{~g}\right.$ protein $\left.\cdot \mathrm{kg}^{-1}\right)$ as a function of increasing SMUF concentration $(0-1.0)$. profiles obtained for the re-micellised casein in SMUF or water and phosphocasein in SMUF were similar to profiles obtained for skim milk by Horne and Parker [9]. Horne and Parker [10] suggested that the increased ethanol stability of milk with increased $\mathrm{pH}$ was due to increased soluble phosphate acting as a calcium sequestrant resulting in decreased negative charge and an increased energy barrier to coagulation. A similar effect may explain the greater ethanol stability with increasing $\mathrm{pH}$ of the model caseins in this study. However, it must be concluded that phosphocasein and to a lesser extent, remicellised casein dispersions are dependent on the milk soluble salts to remain stable to increasing concentrations of ethanol. The data outlined in Figure 6 shows the effect of increasing SMUF concentration (0-1.0) on the resulting ethanol stability of phosphocasein $\left(25 \mathrm{~g} \cdot \mathrm{kg}^{-1}\right)$. It was shown that a minimum concentration (0.6 SMUF) of the soluble milk salts was required to increase the ethanol stability from a basic level of 

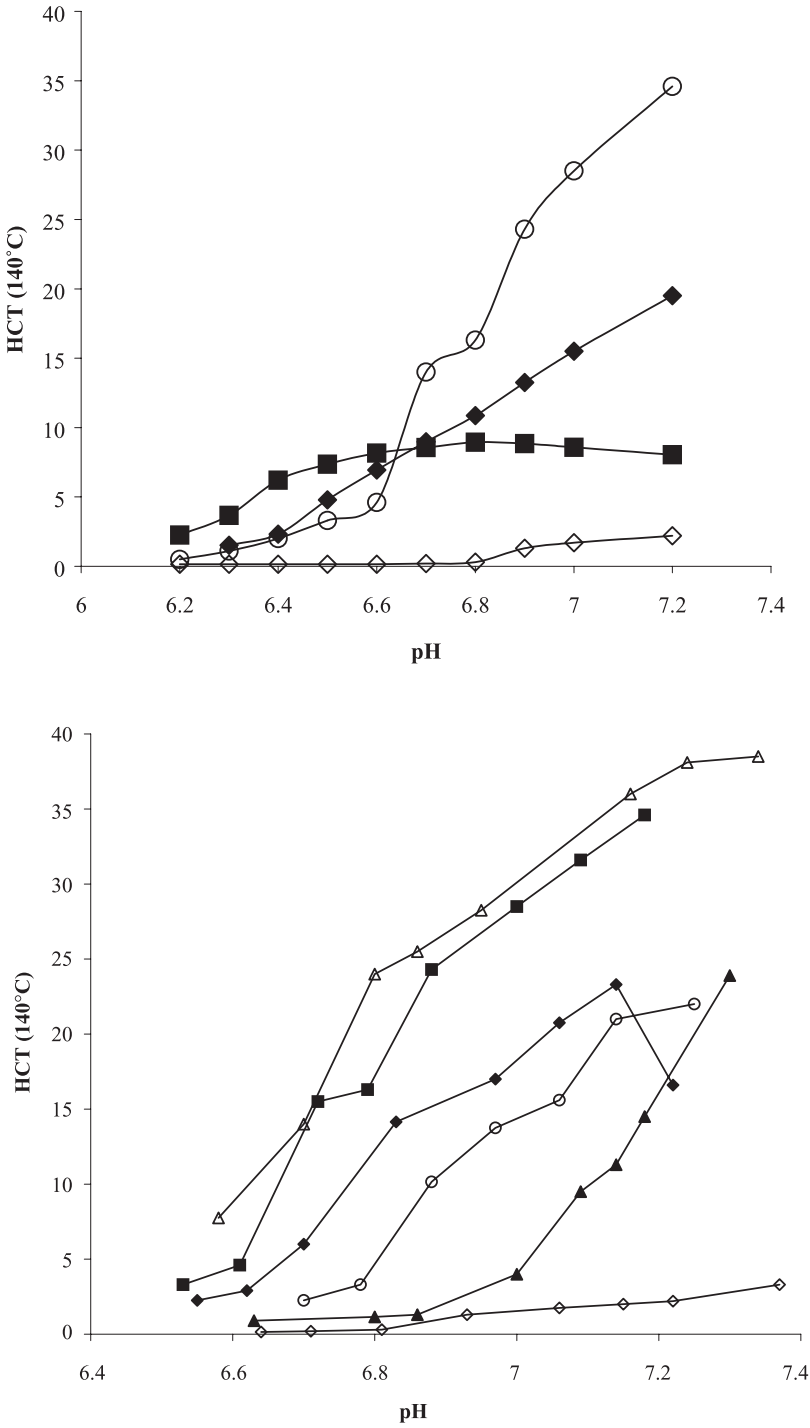

Figure 7. $\mathrm{HCT} / \mathrm{pH}$ profiles $\left(25 \mathrm{~g}\right.$ protein $\left.\cdot \mathrm{kg}^{-1}, 140^{\circ} \mathrm{C}\right)$ of re-micellised casein in SMUF (घ) or water ( ) or phosphocasein in $\operatorname{SMUF}(\mathrm{O})$ or water $(\diamond)$.

Figure 8. HCT $/ \mathrm{pH}$ profiles $\left(140{ }^{\circ} \mathrm{C}\right)$ of phosphocasein $\left(25\right.$ g protein $\left.\cdot \mathrm{kg}^{-1}\right)$ in water $(\diamond)$, or in SMUF 0.2( $\Delta)$, SMUF 0.4 (O), SMUF 0.6( ), SMUF 0.8 $(\Delta)$ or SMUF $1.0(\mathbf{\square})$.

$216 \mathrm{~mL} \cdot \mathrm{L}^{-1}$ ethanol to the normal level observed in milk at $\mathrm{pH} 7.0\left(\sim 600 \mathrm{~mL} \cdot \mathrm{L}^{-1}\right)$.

\subsection{Heat stability}

HCT-pH profiles of $25 \mathrm{~g} \cdot \mathrm{kg}^{-1}$ phosphocasein and re-micellised casein at $140{ }^{\circ} \mathrm{C}$ are shown in Figure 7. When dispersed in water, phosphocasein had little heat stability over the entire $\mathrm{pH}$ range going from a HCT of $0.15 \mathrm{~min}$ at $\mathrm{pH} 6.2$ that increased slightly to 0.3 min at $\mathrm{pH} 6.8$ and only reached a value of $2.2 \mathrm{~min}$ at $\mathrm{pH} 7.2$. However, stability to heat was markedly restored when dispersed in SMUF, especially at $\mathrm{pH}>6.6$. Phosphocasein when dispersed in SMUF had a minimum value of HCT $(0.5 \mathrm{~min})$ at $\mathrm{pH} 6.2$ that increased gradually to $4.6 \mathrm{~min}$ at $\mathrm{pH} 6.6$ before increasing at a greater rate to $34.6 \mathrm{~min}$ at $\mathrm{pH}$ 7.2. Figure 8 shows the effect of increasing SMUF concentration (0-1.0) on 
the resulting HCT-pH profiles at $140{ }^{\circ} \mathrm{C}$ of phosphocasein $\left(25 \mathrm{~g} \cdot \mathrm{kg}^{-1}\right)$. With each incremental increase in salt level the HCT of phosphocasein increased at every $\mathrm{pH}$.

Re-micellised casein, in contrast to phosphocasein, had adequate stability to heat in the absence of added SMUF and a reduced stability at $\mathrm{pH}>6.7$ in the presence of SMUF. $25 \mathrm{~g} \cdot \mathrm{kg}^{-1}$ re-micellised casein in SMUF had a HCT that increased from a minimum value of $2.25 \mathrm{~min}$ at $\mathrm{pH} 6.2$ to a maximum of $9 \mathrm{~min}$ at $\mathrm{pH} 6.8$ before decreasing to $8.1 \mathrm{~min}$ at $\mathrm{pH} 7.2 .25 \mathrm{~g} \cdot \mathrm{kg}^{-1}$ re-micellised casein in water had lower HCT than in SMUF at pH values of 6.6 and lower. It had a HCT of $1.5 \mathrm{~min}$ at $\mathrm{pH} 6.2$ that increased with increasing $\mathrm{pH}$, reaching a value of $19.5 \mathrm{~min}$ at $\mathrm{pH} 7.2$.

The most important factor affecting the HCT of milk is the pH [27]. Most milk shows a HCT peak at $\mathrm{pH} 6.7$ followed by a minimum at $\mathrm{pH} 6.9$ with the stability increasing again above this $\mathrm{pH}$ [27]. The lowering of heat stability with reducing $\mathrm{pH}$ from 6.7 down to 6.2 is possibly largely due to the ionic environment. As the $\mathrm{pH}$ of phosphocasein or milk is lowered the increased protonation of protein groups decreases the net negative charge of the casein micelle [28] and the amount of soluble $\mathrm{Ca}^{2+}$ ions increases due to the solubilisation of colloidal calcium phosphate $[4,21]$. This soluble Ca reduces the zeta potential of the casein by neutralisation of negative residues such as phosphoserine and carboxylic [29]. Charge neutralisation would partially collapse the $\kappa$-casein on the micelles surface and enhance aggregation and precipitation processes due to a reduction in electrostatic and steric stabilisation [32]. The increased $\mathrm{NaCl}$ present in re-micellised casein probably contributed to its increased heat stability at $\mathrm{pH} \leq 6.6$ under both low and higher ionic strength conditions compared to phosphocasein.

\section{CONCLUSION}

Casein can be re-micellised from the insoluble acid casein form using a simplified ionic environment of calcium and phosphate salts and still exhibit functional characteristics such as rennetability, acid gelation, ethanol and heat stability. Differences observed between re-micellised casein functionality and micellar casein (phosphocasein) functionality were attributed partly to ionic strength effects, particularly the higher salt content in the re-micellised casein. The functional attributes of re-micellised casein suggest that it could be a viable alternative to phosphocasein where high protein ingredients with micellar-casein type functionality are a requirement in the food industry.

Acknowledgements: This project was financially supported under the National Development Plan (FIRM-Funding). The authors are indebted to J. Mounier for translation of the abstract into French.

\section{REFERENCES}

[1] Auty M.A.E., O’Kennedy B.T., Allan-Wojtas P., Mulvihill D.M., The application of microscopy and rheology to study the effect of milk salt concentration on the structure of acidified micellar casein systems, Food Hydrocolloids 19 (2005) 101-109.

[2] Davies D.T., Law A.J.R., Variation in the protein composition of bovine casein micelles and serum casein in relation to micellar size and milk temperature, J. Dairy Res. 50 (1983) 67-85.

[3] Davies D.T., White J.C.D., The stability of milk proteins to heat: 1 . Subjective measurement of heat stability of milk, J. Dairy Res. 33 (1966) 67-81.

[4] De Kruif C.G., Attractive interactions and aggregation in food dispersions, in: Dickenson E., Rodriquez Patino J. M. (Eds.), Food Emulsions and Foams: interfaces, interactions and stability, Royal Society of Chemistry, Great Britain, 1999, pp. 29-44.

[5] Famelart M.H., Lepesant F., Gaucheron F., Le Graët Y., Schuck P., pH-Induced physiochemical modifications of native phosphocaseinate suspensions: Influence of aqueous phase, Lait 76 (1996) 445-460.

[6] Fox P.F., McSweeney P.H.L., Dairy Chemistry and Biochemistry, Aspen Publishers, Inc. MD, USA, 1998, pp. 384-386.

[7] Grufferty M.B., Fox P.F., Effect of added $\mathrm{NaCl}$ on some physiochemical properties of milk, Ir. J. Food Sci. Technol. 9 (1985) 1-9. 
[8] Horne D.S., Casein interactions: casting light on the black boxes, the structure in dairy products, Int. Dairy J. 8 (1998) 171-177.

[9] Horne D.S., Parker T.G., Factors affecting the ethanol stability of bovine milk. I. Effect of serum phase components, J. Dairy Res. 48 (1981) 273-284.

[10] Horne D.S., Parker T.G., Factors affecting the ethanol stability of bovine milk. II. The origin of the $\mathrm{pH}$ transition, J. Dairy Res. 48 (1981) 285-291.

[11] Horne D.S., Parker T.G., Factors affecting the ethanol stability of bovine milk. III. Substitution of ethanol by other organic solvents, Int. J. Biol. Macromol. 3 (1981) 399-402.

[12] Horne D.S., Parker T.G., Factors affecting the ethanol stability of bovine milk. V. Effect of chemical modification of milk protein, J. Dairy Res. 49 (1982) 449-457.

[13] Jenness R., Koops J., Preparation and properties of a salt solution which simulates milk ultrafiltrate, Neth. Milk Dairy J. 16 (1962) 153-164.

[14] Kelly P.M., Kelly J., Mehra R., Oldfield D.J., Raggett E., O'Kennedy B.T., Implementation of integrated membrane processes for pilot-scale development of fractionated milk components, Lait 80 (2000) 139-153.

[15] Le Ray C., Maubois J.L., Gaucheron F., Brulé G., Pronnier P., Garnier F., Heat stability of reconstituted casein micelle dispersions: changes induced by salt addition, Lait 78 (1998) 373-390.

[16] Mulvihill D.M., Caseins and caseinates: manufacture, in: Fox P.F. (Ed.), Developments in Dairy Chemistry, Vol.4: Functional Proteins, Elsevier Applied Science Publishers, London, UK, 1989, pp. 97-130.

[17] O’Kennedy B.T., Cribbin M., Kelly P.M., Stability of sodium caseinate to ethanol, Milchwissenschaft 56 (2001) 680-684.

[18] Pierre A., Milk stability in ethanolic solutions, J. Dairy Res. 56 (1989) 521-527.

[19] Pierre A., Fauquant J., Le Graët Y., Piot M., Maubois J.L., Préparation de phosphocaséinate natif par microfiltration sur membrane, Lait 75 (1992) 461-474.

[20] Pires M.S., Orellana G.A., Gatti C.A., Rennet coagulation of casein micelles and heated casein micelles: action of $\mathrm{Ca}^{2+}$ and $\mathrm{pH}$, Food Hydrocolloids 13 (1999) 235-238.
[21] Roefs S.P., van Vliet T., Structure of acid casein gels. 2. Dynamic measurements and type of interaction forces, Colloids Surf. 50 (1990) 161-175.

[22] Roeper J., Preparation of calcium caseinate from casein curd, N. Z. J. Dairy Sci. 12 (1977) 182-189.

[23] Rose D., Davies D.T., Yaguchi M., Quantitative determination of the major components of casein mixtures by column chromatography on DEAE-cellulose, J. Dairy Sci. 52 (1969) 8-11.

[24] Schmidt D.G., Koops J., Westerbeek D., Properties of artificial casein micelles. 1. Preparation, size distribution and composition, Neth. Milk Dairy J. 31 (1977) 328-341.

[25] Schmidt D.G., van der Spek C.A., Buchheim W., Hinz A., On the formation of artificial casein micelles, Milchwissenschaft 29 (1974) 455-459.

[26] Schuck P., Piot M., Méjean S., Fauquant J., Brulé G., Maubois J.L., Deshydratation des laits enrichis en caséine micellaire par microfiltration; comparaison des propriétés des poudres obtenues avec celles d'une poudre de lait ultra-propre, Lait 74 (1994) 47-63.

[27] Singh H., Heat stability of milk, Int. J. Dairy Technol. 57 (2004) 111-119.

[28] van Hooydonk A.C.M., Hagedoorn H.G., Boerrigter I.J., pH-induced physico-chemical changes in casein micelles in milk and their effect on renneting 1. Effect of acidification on physico-chemical properties, Neth. Milk Dairy J. 40 (1986) 281-296.

[29] van Hooydonk A.C.M., Hagedoorn H.G., Boerrigter I.J., The effect of various cations on the renneting of milk, Neth. Milk Dairy J. 40 (1986) 369-390.

[30] Visser S., van Rooijen P.J., Slangen C.J., Peptide substrates for chymosin (rennin). Isolation and substrate behaviour of two tryptic fragments of bovine $\kappa$-casein, Eur. J. Biochem. 108 (1980) 415-421.

[31] Walsh-O'Grady C.D., O'Kennedy B.T., Fitzgerald R.J., Lane C.N., A rheological study of acid-set "simulated yoghurt milk" gels prepared from heat- or pressure-treated milk proteins, Lait 81 (2001) 637-650.

[32] Walstra P.J., On the stability of casein micelles, J. Dairy Sci. 73 (1990) 1965-1979. 